\title{
The effects of melatonin treatment on wool production and hair follicle cycle in angora rabbits
}

\author{
József LANSZKI $^{\mathrm{a} *}$, René-Gérard THÉBAULT ${ }^{\mathrm{b}}$, Daniel ALLAIN ${ }^{\mathrm{c}}$, \\ Zsolt SZENDRÕ ${ }^{\mathrm{a}}$, Csilla EIBEN ${ }^{\mathrm{d}}$ \\ a University of Kaposvár, Faculty of Animal Science, PO Box 16, 7401 Kaposvár, Hungary \\ b INRA, UE Génétique Animale Phanères, Le Magneraud, BP 52, 17700 Surgères, France \\ ' INRA, Station d'Amélioration Génétique des Animaux, BP 27, \\ 31326 Castanet-Tolosan Cedex, France \\ d Institute for Small Animal Research, PO Box 417, 2101 Gödöllõ, Hungary
}

(Received 14 April 2000; accepted 4 December 2000)

\begin{abstract}
The aims of this study were to examine the effect of melatonin treatment on (1) the quantity of wool production and fibre quality traits, (2) feed consumption and body weight and (3) hair follicle activity in the German angora rabbits. The study involved 106 male and female angora rabbits (raised under natural photoperiod), between the initial ages of 200-210 days. Half of the stock was treated with melatonin (36 mg per rabbit) either in May prior to the summer solstice, or in July subsequent to the solstice. Other animals served as untreated controls. In May two methods of wool harvesting: defleecing or shearing, were tested, while in July two different intervals between wool harvests, 98 and 80 days, were compared. Skin samples were taken from May onwards six times during the experimental period. Melatonin treatment increased significantly total wool production (by $17.7 \%, P<0.01$ ), weight of first grade wool (by $14.1 \%, P<0.01$ ), fibre length (by $5.6 \%, P<0.001$ ), wool production per day (by $17.3 \%, P<0.01$ ) and per $\mathrm{kg}$ of live weight (by $14.6 \%, P<0.05)$. The melatonin treatment also led to a significant increase in feed consumption and body weight during the first weeks following melatonin treatment. Melatonin treatment did not exert any significant effect on the content of the different fibre types, or on bristle dimensions (area and diameter), but resulted in a $32 \%(P<0.001)$ increase in the number of active follicles (lateral primaries and secondaries) per hair follicle group. The date of treatment had a significant influence on the quantity of first grade wool with higher production observed only when animals are treated in July. The treatment proved to be more effective in the defleeced rabbits than in the shorn ones.
\end{abstract}

melatonin / angora rabbit / wool production / fibre characteristic/ hair follicle activity

Résumé - Effets de la mélatonine sur la production de laine et le cycle d'activité des follicules pileux chez le lapin angora. Cette étude avait pour but d'examiner les effets de la mélatonine (1) sur la morphologie des fibres et la production pondérale de laine, (2) sur le poids vif et l'ingestion de

* Correspondence and reprints

Tel.: 36823141 55; fax: 36823201 75; e-mail: lanszki @ atk.kaposvar.pate.hu 
nourriture et (3) sur le cycle d'activité des follicules pileux chez le lapin angora allemand. L'étude a porté sur 106 lapins angora, mâles et femelles, âgés de 200 à 210 jours au début de l'expérience et élevés sous photopériode naturelle. La moitié d'entre eux a reçu un traitement à la mélatonine $(36 \mathrm{mg}$ par lapin), un premier groupe au mois de mai, avant le solstice d'été, un autre groupe en juillet, après le solstice. Les animaux non traités ont servi de témoins. En mai, deux méthodes de récolte de la toison ont été pratiquées : l'épilation et la tonte ; alors qu'en juillet, deux intervalles entre récoltes : 80 et 98 jours ont été comparés. Six échantillons de peau par animal ont été prélevés à partir de mai, durant toute la période expérimentale. Le traitement à la mélatonine a augmenté significativement la production totale de laine $(+17,7 \%, P<0,01)$, le poids de la laine de $1^{\text {re }}$ qualité $(+14,1 \%, P<0,01)$, la longueur des fibres $(+5,6 \%, P<0,001)$, la production de laine par jour $(+7,3 \%, P<0,01)$ et par $\mathrm{kg}$ de poids vif $(+14,6 \%, P<0,05)$. Le traitement à la mélatonine a également provoqué un accroissement significatif de la consommation d'aliment et du poids vif, durant les premières semaines du traitement. En revanche, aucun effet significatif n'a été observé sur les dimensions des « jarres » (surface et diamètre). Le traitement a augmenté de $32 \%(P<0,001)$ le nombre de follicules pileux (primaires latéraux et secondaires) en activité par groupe folliculaire. La période de traitement a eu un effet significatif $(P<0,001)$ sur la quantité de laine de première classe, ainsi la production des animaux traités au mois de juillet a été plus élevée. Le traitement a été plus efficace chez les lapins épilés que chez les animaux tondus.

mélatonine / lapins angora / production de poils / caractéristiques des fibres / activité des follicules pileux

\section{INTRODUCTION}

In temperate climates the wool production of angora rabbits fluctuates with the seasons, summer production levels being found to be the lowest $[1,13,14,17,18]$ in both French and German strains and irrespective of the method used for wool harvesting, as French rabbits are defleeced and while German ones are shorn [18]. The weight of wool produced is influenced by the number of fibres, their length and their diameter [14]. The number of growing fibres per hair follicle group is determined by the season, through the photoperiod [18] and it has been shown that the ratio of inactive hair follicles is $12 \%$ in spring and 28 to $30 \%$ in summer [13]. In summer the adverse effects of both long day length and hot conditions are simultaneously present. In the defleeced angora does of the French strain the decrease in wool production during summer can be prevented by means of melatonin treatment $[2,15]$. The endocrine control of seasonal changes in body weight, feed intake and hair follicle cycle is complex, but several studies have shown that the photoperiodism is the main regulating factor acting on fibre growth and moulting periods [3-5, 9]. The pineal gland via melatonin secretion and the pituitary gland via prolactin secretion play a role in the neuroendocrine control of hair follicle cycle by photoperiodism. Melatonin secretion is higher in dark (short day) period and lower in light (long day) period. However, the mechanism of the hormonal regulation of the hair follicle cycle is not yet known satisfactory $[5,8]$. Furthermore the feeding level has influence on wool and hair follicles [6].

No information is available about melatonin treatment effects in the German angora rabbit, in which wool is usually harvested by shearing.

The objective of this experiment was to examine the effect of melatonin treatment on (1) the quantity of wool produced, fibre length and fibre characters, (2) feed consumption and body weight and (3) the number of hair follicles (lateral primaries and secondaries) per follicle group and hair follicle activity in the German angora rabbit, with particular regard to the method used 
for harvesting the wool, the date of melatonin administration, the sex of the animals and the interval between two harvests.

\section{MATERIALS AND METHODS}

\subsection{Animals and housing}

A total of 106 German type angora rabbits of 200-210 days of age (after the third shearing or defleecing) at the beginning of the experiment were used in the study. The animals were kept in a closed building with windows, according to a natural photope$\operatorname{riod}\left(46^{\circ} 40^{\prime} \mathrm{N}\right)$, in individual flat-deck cages. There was no climate control in the rabbit house, ventilation being provided naturally, through windows covered with mosquito net, from spring to autumn. In winter the building was heated by means of warm air flow. The temperature sometimes rose above $25^{\circ} \mathrm{C}$ in summer, but remained between approximately 13 and $15^{\circ} \mathrm{C}$ in winter. The animals were fed ad libitum with pelleted feed (CP: 17.1, CF: 13.2, DE: $10.3 \mathrm{MJ} \cdot \mathrm{kg}^{-1}$ ), and hay was given once a week to prevent trichobezoar. The animals were weighed and feed consumption was recorded at weekly intervals.

\subsection{Experimental procedure}

The animals were assigned into two groups at random (Tab. I): one group treated with melatonin (M: $36 \mathrm{mg}$ per animal) either in spring before the summer solstice (on 6 and 13 of May), or in summer (on 5, 18 and 24 of July), and a control group (C) with no treatment. Melatonin was administered by means of Regulin subcutaneous implant, containing $18 \mathrm{mg}$ melatonin (Hoechst UK Ltd., catalogue No. 0086/4176). Average body weight and weight of the wool at the previous shearing or defleecing were similar in each group. In the experimental group treated with melatonin in May two methods for harvesting the wool, shearing and defleecing, were used. The interval between two harvests was generally 98 days, except in some animals in the summer groups, with an interval of 80 days.

\subsection{Measurement of fibre traits}

Throughout the experimental period hair length was measured every 10 days on three locations on the body: (1) the backbone, in the hind quarters region, (2) on the right thigh, and (3) on the right shoulder blade at five points. When animals were defleeced, the rabbits were fed prior to defleecing with Lagodendron-R mix (Trade Mark, Proval SA, Paris, France). At harvest the fleeces were weighed and graded on the basis of fibre length; those graded as first class had fibres over $60 \mathrm{~mm}$ in length and were clean. At the end of the experiment (on day 98) fleece samples $\left(1 \mathrm{~cm}^{2}\right.$ area) were taken from the back region of the hip of each animal. Then fibre cross sections of $50 \mu \mathrm{m}$ thickness suitable for microscope examination [14] were made with on ITF-Fibrotome

Table I. Experimental design and number of males (m) and females (f) in each treatment group.

\begin{tabular}{|c|c|c|c|c|c|}
\hline \multirow[t]{2}{*}{ Date of treatment } & \multirow{2}{*}{$\begin{array}{l}\text { Interval } \\
\text { between } \\
\text { harvests }\end{array}$} & \multicolumn{2}{|c|}{ Melatonin treated group } & \multicolumn{2}{|c|}{ Control group } \\
\hline & & Shearing & Defleecing & Shearing & Defleecing \\
\hline May & 98 days & $10 \mathrm{~m}+10 \mathrm{f}$ & $8 \mathrm{f}$ & $10 \mathrm{~m}+10 \mathrm{f}$ & $8 \mathrm{f}$ \\
\hline July & $\begin{array}{l}98 \text { days } \\
80 \text { days }\end{array}$ & $\begin{array}{c}15 \mathrm{~m}+5 \mathrm{f} \\
5 \mathrm{~m}\end{array}$ & & $\begin{array}{c}15 \mathrm{~m}+5 \mathrm{f} \\
5 \mathrm{~m}\end{array}$ & \\
\hline
\end{tabular}


(Instrument SA). The microscope image analysis and evaluation of the different hair types (tylotriches, bristles and awns) was performed by means of a specific procedure developed with the Visilog (1988) vision software [20].

\subsection{Skin histological examination/procedures}

Skin samples $\left(33 \mathrm{~mm}^{2}\right.$ area) were taken at the beginning of the experiment, and subsequently after 2, 4, 8, 12 and 14 weeks, from the dorsal region of the pelvis, in 16 defleeced females, 10 shorn females and 10 shorn males. The skin sampling procedure by biopsy was performed with local anaesthetic (by the use of Lidocain spray) and use of disinfectant thereafter (with aluminiumspray). Skin samples were stored in $10 \%$ formalin solution, then in Bouin solution for the 24 hours immediately prior to processing. Sectioning of skin samples at $7 \mu \mathrm{m}$ thickness was performed by means of paraffin sections with Mikrotom apparatus at the level of the sebaceous gland. The ROAN procedure [14] was used for the staining of the sections. The histological evaluation procedure was performed with a light microscope by counting 10-20 hair follicle groups per sample and determining the following parameters: (1) the number of hair follicles in anagen and telogen phases (lateral primaries and secondaries) in the central hair follicle group; (2) the proportion of growing fibres per follicle group in relation to the total number of hair fibres in the follicle group $[1,15,18]$.

\subsection{Statistical procedures}

The data were analysed by means of the SAS GLM procedure [16]. The following variables were studied: total fleece weight, weight of 1st class wool, quantity of wool produced per day and per kg of body weight, average daily feed intake, body weight, hair length, the ratio of anagen and the number of anagen, telogen and total hairs per group. The following fixed effect model of variance analysis was used:

$$
\begin{aligned}
\mathrm{Y}_{\mathrm{ijklmn}}= & \mu+\text { MELT }_{\mathrm{i}}+\mathrm{HM}_{\mathrm{j}} \\
& +\mathrm{MELTxHM}_{\mathrm{ij}}+\mathrm{T}_{\mathrm{k}}+\mathrm{S}_{1} \\
& +\mathrm{IT}_{\mathrm{mk}} 057+\mathrm{b}\left(\mathrm{Bwo}_{\mathrm{B} w}\right)+\mathrm{e}_{\mathrm{ijklmn}}
\end{aligned}
$$

where: $\mathrm{Y}_{\mathrm{ijklmn}}$ is the nth observation on the ith experimental group, the jth method of fleece harvest, the ijth melatonin $\times$ harvesting method interaction, the kth treatment period, the lth sex, the mth interval between harvest within treatment period; $\mu$ the overall mean; MELT $_{\mathrm{i}}$ the treatment effect $(\mathrm{i}=2$, melatonin or control); $\mathrm{HM}_{\mathrm{j}}$ the harvesting method effect $(j=2$, defleecing or shearing); MELT $\times \mathrm{HM}_{\mathrm{ij}}$ the melatonin treatment $\times$ harvesting method interaction; $\mathrm{T}_{\mathrm{k}}$ the treatment time effect $(\mathrm{k}=2$, spring or summer); $S_{1}$ the sex effect $(1=2$, male or female); IT $_{\mathrm{mk}}$ the effect of the interval between two harvests within the treatment period ( $m=2,98$ or 80 days); b a linear regression coefficient for body weight (taken into account only for total and first class wool production, wool production per day and feed intake); Bwo the individual body weight at beginning of experiment; $\mathrm{Bw}$ the overall mean body weight at beginning of experiment and $\mathrm{e}_{\mathrm{ijklmn}}$ the random error. The variable effects used for studying fibre quality traits and hair follicle cycle were MELT, $\mathrm{HM}, \mathrm{MELT} \times \mathrm{HM}$ and S. Statistical significance for each effect, including the significance of the linear regression coefficients, was tested by means of F test. Significance analysis of the falling out rate recorded in the course of the experiment was performed by $\chi^{2}$-test.

\section{RESULTS}

\subsection{Feed intake, feed conversion and body weight}

Feed consumption was significantly higher by about $22-30 \%(P<0.01$ or $P<0.05)$ in melatonin-treated group than in the control group from the 2nd to the 9th week (Fig. 1), 
Figure 1. Feed consumption of melatonintreated $(-)$ and control (O) angora rabbits. Arrow indicates the time of melatonin treatment and vertical bars the standard error of mean; polynomial trendlines are fit to the mean data; $* P<0.05$, $* * P<0.01$.

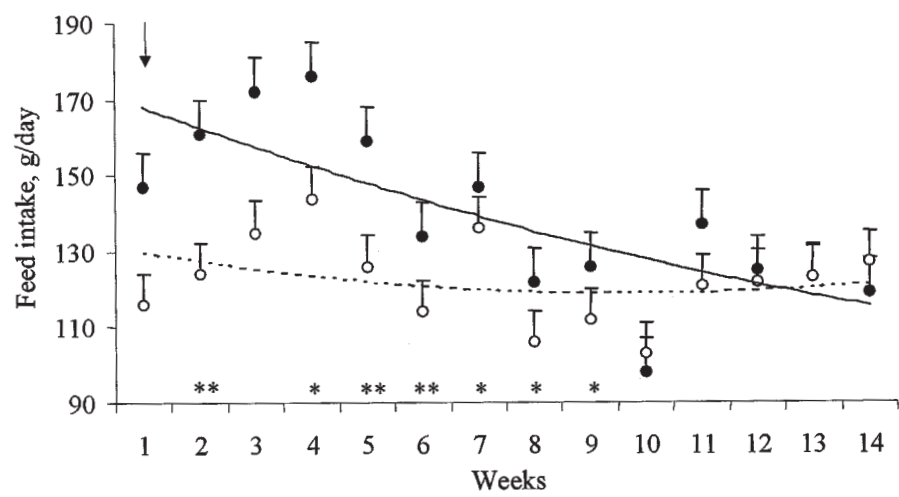

by $15-42 \%(P<0.001$ or $P<0.01)$ in summer-treated group than in those treated in spring from the 5 th week after wool harvest, and by $22-42 \%(P<0.01-0.05)$ in the defleeced rabbits than in the shorn group from the 8 th to the 14 th week. Feed intake was still increasing from the 11th to the 14th week in defleeced rabbits while it was already decreased in the other group during the summer period.

The average feed conversion $(\mathrm{kg}$ pellet per $\mathrm{kg}$ wool) was $66 \mathrm{~kg}$ during the experimental period. It was significantly better in melatonin-treated group than in control one (63.2 vs. $\left.69.4 \mathrm{~kg} \cdot \mathrm{kg}^{-1}, P<0.01\right)$, and in the sheared group than in defleeced animals (67.0 vs. $\left.65.9 \mathrm{~kg} \cdot \mathrm{kg}^{-1}, P<0.05\right)$.

Body weight was influenced by melatonin-treatment. It increased at a faster rate in melatonin-treated rabbits (Fig. 2) and was significantly higher by $4-6 \%(P<0.01$ or $P<0.05)$ than in controls from the 4th week. The time of melatonin administration influenced body weight mainly in the final phase of the experimental period. The female rabbits were heavier than males by $10 \%$ $(P<0.001)$.

No significant difference $\left(\chi^{2}=72.86\right.$, df $=67, P=0.291, n=106)$ in falling out rate (culling because of sickness and mortality) could be ascribed to the effect of the treatment.

\subsection{Wool production}

Exogenous melatonin administration exerted a considerable effect on the quantity
Figure 2. Body weight of melatonin-treated ( and control $(\mathrm{O})$ angora rabbits. Arrow indicates the time of melatonin treatment and vertical bars the standard error of mean; polynomial trendlines are fit to the mean data; $* P<0.05$, ** $P<0.01$.

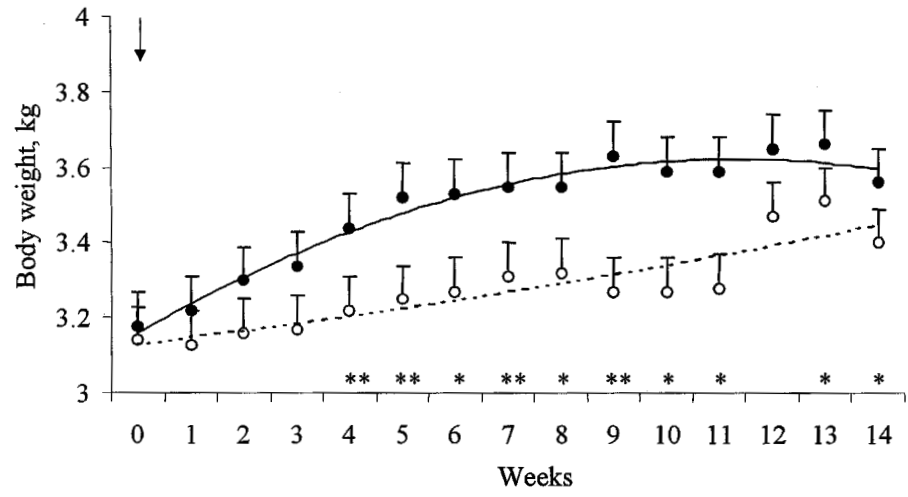


of wool produced (Tab. II). Total fleece weight as well as weight of first grade wool, and quantity of wool produced per day and per $\mathrm{kg}$ of live weight were 14 to $18 \%$ higher $(P<0.01$ or $P<0.05)$ in the melatonin treated group than in the controls. There was a significant interaction between treatment and harvesting method on wool production per day. The treatment given proved more effective in the defleeced rabbits than in those shorn. The time of melatonin administration exerted a significant influence on total fleece weight per animal $\mathrm{kg}$ of body weight, with a higher production observed in rabbits treated in July (Tab. II). Wool production increased with the interval between two harvests. However the daily wool production was better (by $17 \%, P<0.01$ ) with a 80 days interval between harvests. There was no significant sex effect.

\subsection{Fibre length and fibre characteristics}

Melatonin treatment always led to a significant increase in fibre length (Tab. III). Larger differences in hair length were observed among the defleeced rabbits than among those shorn (by $8.6 \%$ and $2.6 \%$ respectively). Throughout the experimental period wool was longer in shorn than in defleeced rabbits. However, the growth rate in fibre length was higher in defleeced rabbits than in shorn ones so the difference between the two groups decreased from the beginning to the end of experimental period. A significant interaction between the treatment and the method used for harvesting the wool was found.

The melatonin treatment did not exert a significant effect on the ratio of the different

Table II. Wool traits (estimates within effect) of melatonin-treated and control angora rabbits.

\begin{tabular}{lcccc}
\hline \multicolumn{1}{c}{ Trait } & \multicolumn{4}{c}{ Fleece weight $(\mathrm{g})$} \\
\cline { 2 - 5 } & total & 1st class & per day & per kg Bw \\
\hline Overall mean & 188 & 100 & 1.95 & 58.7 \\
RSD & 27 & 27 & 0.28 & 9.0 \\
Melatonin treatment effect & $* * *$ & $* * *$ & $* * *$ & $* * *$ \\
$\quad$ melatonin $(\mathrm{n}=48)-$ control $(\mathrm{n}=47)$ & 46 & 28 & 0.47 & 13.5 \\
Harvesting method effect & $\mathrm{ns}$ & $* * *$ & $\mathrm{~ns}$ & $\mathrm{~ns}$ \\
$\quad$ defleeced $(\mathrm{n}=13)-$ shorn $(\mathrm{n}=82)$ & -5 & 74 & -0.05 & -2.1 \\
Melatonin $\times$ harvest method & $* *$ & $*$ & $* *$ & $* *$ \\
$\quad$ treated, defleeced $(\mathrm{n}=6)(\mathrm{LSM}$ value) & $210 \mathrm{a}$ & $182 \mathrm{a}$ & $2.22 \mathrm{a}$ & $64.6 \mathrm{a}$ \\
$\quad$ control, defleeced $(\mathrm{n}=7)$ & $140 \mathrm{~b}$ & $133 \mathrm{c}$ & $1.51 \mathrm{~b}$ & $43.8 \mathrm{c}$ \\
$\quad$ treated, shorn $(\mathrm{n}=42)$ & $192 \mathrm{a}$ & $86 \mathrm{~b}$ & $2.04 \mathrm{a}$ & $59.4 \mathrm{a}$ \\
$\quad$ control, shorn $(\mathrm{n}=40)$ & $169 \mathrm{c}$ & $79 \mathrm{~b}$ & $1.81 \mathrm{c}$ & $53.1 \mathrm{~b}$ \\
Treatment time effect & $* *$ & $\mathrm{~ns}$ & $\mathrm{~ns}$ & $* * *$ \\
$\quad$ spring $(\mathrm{n}=48)-$ summer $(\mathrm{n}=47)$ & 23 & -12 & 0.08 & 9.7 \\
Sex effect & $\mathrm{ns}$ & $\mathrm{ns}$ & $\mathrm{ns}$ & $\mathrm{ns}$ \\
$\quad$ male $(\mathrm{n}=56)-$ female $(\mathrm{n}=39)$ & -10 & -4 & -0.10 & -0.1 \\
Harvest interval within treatment time effect & $* * *$ & $*$ & $* *$ & $* * *$ \\
$\quad 98$ days $(\mathrm{n}=86)-80$ days $(\mathrm{n}=9)$ & 58 & 51 & -0.28 & 17.6 \\
\hline
\end{tabular}

$\mathrm{RSD}=$ residual standard deviation; $\mathrm{n}=$ number of animals; $\mathrm{ns}: P>0.05, * P<0.05, * * P<0.01$, *** $P<0.001$; in melatonin $\times$ harvest method interaction the differences between groups marked with different letters $(a-b-c)$ are significant. 
fibre types or on the cross-sectional area and diameter of the bristles (Tab. IV). But the effect of wool harvesting method was considerable. In defleeced angoras there were more bristles of larger cross-sectional area and diameter within the fleece compared to the control rabbits. The melatonin $\times$ harvest method interaction was significant only in the case of awns and no sex effect was observed.

Table III. Fibre length (estimates within effect) of melatonin-treated and control angora rabbits.

\begin{tabular}{lcccccccccc}
\hline \multicolumn{1}{c}{ Trait } & \multicolumn{7}{c}{ Days from the beginning of treatment } \\
\cline { 2 - 11 } & 10 & 20 & 30 & 40 & 50 & 60 & 70 & 80 & 90 & 98 \\
\hline Overall mean (in mm) & 9.3 & 18.5 & 27.9 & 36.9 & 45.5 & 54.2 & 60.5 & 67.6 & 72.6 & 77.4 \\
RSD & 2.0 & 2.2 & 2.2 & 3.1 & 3.8 & 4.1 & 3.6 & 3.7 & 4.1 & 4.4 \\
Melatonin treatment effect & $\mathrm{ns}$ & $* * *$ & $* * *$ & $* * *$ & $* * *$ & $* * *$ & $* * *$ & $* * *$ & $* * *$ & $* * *$ \\
$\quad$ melatonin - control & 0.2 & 1.3 & 1.6 & 2.9 & 3.9 & 4.7 & 4.0 & 4.6 & 4.5 & 4.4 \\
$\quad$ Harvesting method effect & $* * *$ & $* * *$ & $* * *$ & $* * *$ & $* * *$ & $* * *$ & $* * *$ & $* * *$ & $* * *$ & $* * *$ \\
$\quad$ defleeced - shorn & -10.7 & -13.0 & -13.0 & -13.5 & -10.9 & -9.9 & -7.5 & -9.3 & -5.4 & -5.2 \\
Melatonin $\times$ harvest method & $\mathrm{ns}$ & $\mathrm{ns}$ & $\mathrm{ns}$ & $\mathrm{ns}$ & $* * *$ & $* * *$ & $*$ & $* * *$ & $* *$ & $* * *$ \\
Treatment time effect & $* * *$ & $\mathrm{~ns}$ & $* * *$ & $* * *$ & $* * *$ & $* * *$ & $\mathrm{~ns}$ & $* * *$ & $\mathrm{~ns}$ & $* * *$ \\
$\quad$ spring - summer & -0.8 & 0.1 & 3.0 & 3.9 & 2.7 & 2.9 & 0.3 & -2.9 & 0.0 & 1.0 \\
Sex effect & $* * *$ & $* *$ & $* * *$ & $* * *$ & $* * *$ & $* * *$ & $* * *$ & $*$ & $* * *$ & $* * *$ \\
$\quad$ male - female & 0.7 & 0.4 & -1 & 0.8 & 2.5 & 1.9 & 1.4 & 0.5 & 1.3 & 2.1 \\
Harvest interval effect & $* * *$ & $*$ & $\mathrm{~ns}$ & $* * *$ & $\mathrm{~ns}$ & $* * *$ & $*$ & $* * *$ & - & -
\end{tabular}

Abbreviations: see Table II.

Table IV. Number of bristles and awns per sample and cross-sectional area of bristle lock (estimates within effect).

\begin{tabular}{|c|c|c|c|c|c|c|}
\hline \multirow[t]{2}{*}{ Trait } & \multicolumn{4}{|c|}{ Number of hairs of each type per sample } & \multicolumn{2}{|c|}{ Bristle } \\
\hline & TYL & $\mathrm{BR}$ & TYL + BR & Awns & surface $\mu \mathrm{m}^{2}$ & diameter $\mu \mathrm{m}$ \\
\hline Overall mean & 1.0 & 26.7 & 33.8 & 20.6 & 1291 & 140 \\
\hline RSD & 1.2 & 18.4 & 19.5 & 9.9 & 313 & 163 \\
\hline Melatonin treatment effect & ns & ns & ns & ns & ns & ns \\
\hline$M(n=25)-C(n=24)$ & 0 & -0.2 & -0.5 & -4.8 & -72 & -5 \\
\hline Harvesting method effect & ns & $* * *$ & $* * *$ & ns & $* *$ & $* * *$ \\
\hline defleeced $(n=13)-\operatorname{shorn}(n=36)$ & 0.4 & 26.6 & 27.5 & 7.0 & 595 & 31 \\
\hline Melatonin $\times$ harvest method & ns & ns & ns & $*$ & ns & ns \\
\hline Sex effect & ns & ns & ns & ns & ns & ns \\
\hline male $(n=17)-$ female $(n=32)$ & -0.5 & -2.27 & -2.2 & -2.3 & -338 & -17 \\
\hline
\end{tabular}

$\mathrm{TYL}=$ tylotriches, $\mathrm{BR}=$ bristles, other abbreviations: see Table II. 
Table V. Number of fibres per hair follicle group (estimates within effect) in melatonin-treated (M) and control (C) angora rabbits.

\begin{tabular}{|c|c|c|c|c|c|c|c|c|c|c|c|c|}
\hline & \multicolumn{12}{|c|}{ Time of sampling } \\
\hline & \multicolumn{2}{|c|}{ Start } & \multicolumn{2}{|c|}{ 2nd week } & \multicolumn{2}{|c|}{ 4th week } & \multicolumn{2}{|c|}{ 8th week } & \multicolumn{2}{|c|}{12 th week } & \multicolumn{2}{|c|}{ 14th week } \\
\hline & $\mathrm{A}$ & $\mathrm{S}$ & A & $\mathrm{S}$ & A & $S$ & A & S & $\mathrm{A}$ & S & A & S \\
\hline & \multicolumn{12}{|c|}{ Number of fibres per hair follicle group } \\
\hline Overall mean & 25.4 & 29.6 & 27.1 & 28.8 & 32.8 & 35.5 & 32.0 & 35.0 & 31.7 & 36.7 & 31.2 & 39.0 \\
\hline RSD & 11.1 & 10.8 & 11.3 & 11.4 & 11.9 & 13.3 & 11.2 & 12.0 & 11.8 & 12.9 & 11.9 & 12.0 \\
\hline Melatonin treatment effect & $\mathrm{ns}$ & $\mathrm{ns}$ & $* * *$ & $* *$ & $* * *$ & $* * *$ & $* * *$ & $* * *$ & $* * *$ & $* * *$ & $* * *$ & $* * *$ \\
\hline$M(n=15)-C(n=15)$ & -2.7 & -0.7 & 3.7 & 3.4 & 8.8 & 9.5 & 7.8 & 10.9 & 10.5 & 10.4 & 8.4 & 10.9 \\
\hline Harvesting method effect & $* * *$ & $* * *$ & $* * *$ & $* * *$ & NS & $* * *$ & $* * *$ & $* * *$ & * & $* * *$ & $*$ & $* * *$ \\
\hline defleeced - shorn & -29.4 & -33.4 & -17.3 & -19.8 & -9.3 & -13.1 & -4.0 & -8.3 & -4.5 & -12.7 & 0.9 & -8.7 \\
\hline Melatonin $\times$ harvest method & $*$ & ns & ns & ns & $* * *$ & ns & ns & ns & ns & ns & $\mathrm{ns}$ & $\mathrm{ns}$ \\
\hline Sex effect & $*$ & ns & $\mathrm{ns}$ & $\mathrm{ns}$ & $* * *$ & $*$ & ns & ns & ns & $* *$ & $* * *$ & $* *$ \\
\hline male - female & 16.8 & 16.0 & 12.8 & 13.8 & 10.7 & 10.3 & 1.1 & 6.9 & 6.4 & 12.2 & 4.1 & 8.7 \\
\hline
\end{tabular}

A = anagen fibres, $\mathrm{S}=$ total number of hair in anagen or telogen growth phase, start = beginning of experiment, other abbreviations: see Table II. 


\subsection{Hair follicle cycle}

The melatonin treatment was found to exert a substantial effect on hair follicle cycle (Tab. V). In treated angora rabbits the number of follicles (lateral primaries and secondaries) per hair follicle group was significantly greater than in the control group from the 2nd week and the difference between the groups rose up to $32 \%(P<0.01)$ by the 14 th week.

The harvesting method influenced significantly $(P<0.001)$ the number of fibres per hair follicle group throughout the experimental period (Figs. 3a and 3b). Total number of fibres per hair follicle group remained near constant in shorn animals while it increase in defleeced animals. Thus the large difference was observed between shorn and defleeced animals at the beginning decreased gradually throughout the experiment, but a small significant difference was still observed by the end of the experiment (Tab. V). The interaction between treatment and wool harvesting method was not significant. By the end of the experimental period no difference was found between the treated defleeced and control shorn groups (Figs. 3a and 3b).

A significant sex effect was observed in most cases in the second half of the experimental period (Tab. V). At the end of the experiment the number of fibres per follicle group in the males surpassed that recorded in the females by $24 \%(P<0.01)$.

Due to the melatonin treatment hair follicle activity decreased faster in melatonintreated group, but the ratio of anagen hairs at the end of the experiment were still high in both groups (M: 80, C: $84 \%, P<0.05$; Tab. V).
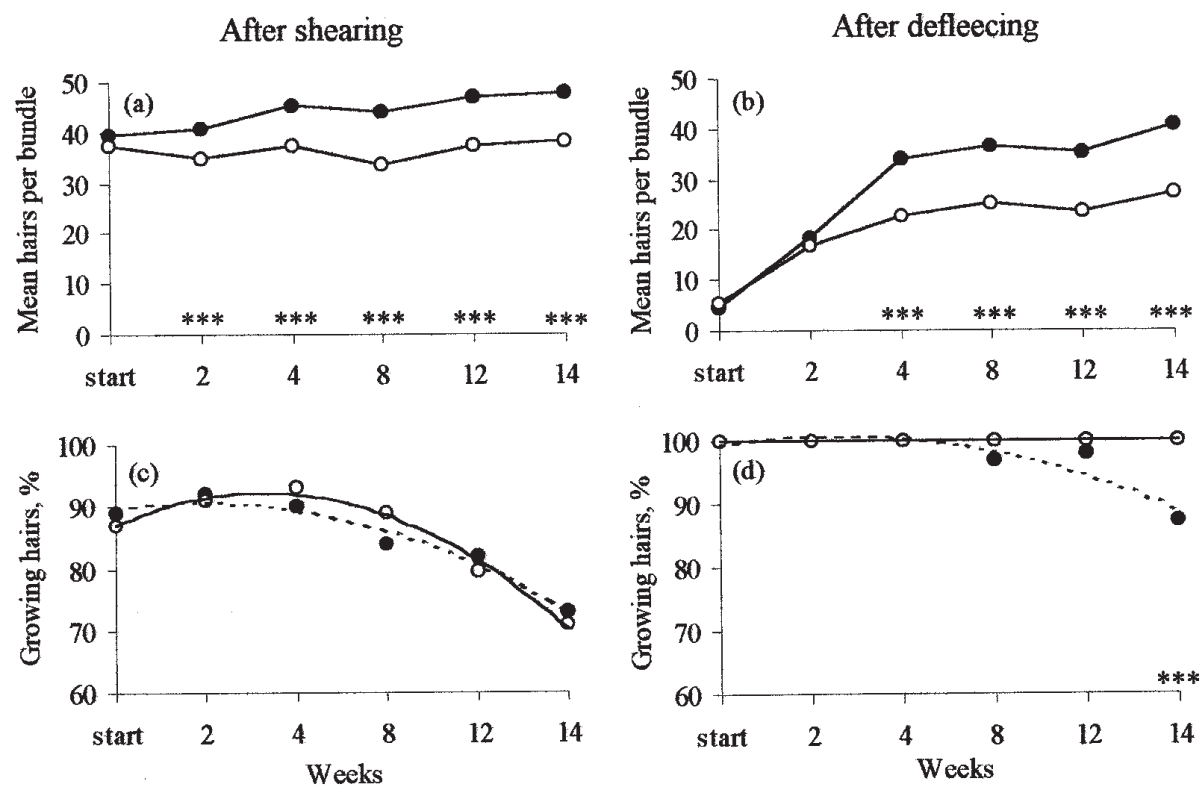

Figure 3. Number of hair fibres per hair follicle bundle in melatonin treated $(-)$ and control groups (O) following hair growth pattern after shearing (a) or after defleecing (b). (above) Hair follicle activity (proportion of hair follicles in the anagen phase) in melatonin treated (o) and control groups (O) following hair growth pattern after shearing (c) or after defleecing (d). (below) Start = beginning of the experiment in May; $* * * P<0.001$. 
The wool harvesting method also influenced hair follicle activity (Figs. $3 \mathrm{c}$ and $3 \mathrm{~d}$ ). In shorn rabbits, the ratio of growing hairs decreased from $95 \%$ at the maximum of activity in the 4th week to $70 \%$ by the end of the experimental period. No significant difference due to the treatment was observed in the shorn groups with respect to the proportion of hair fibres in the process of growth (Fig. 3c). When rabbits were defleeced no hair follicles in the telogen phase were found in the control group, while in melatonin-treated rabbits $13 \%$ of hair follicles were in the telogen phase in the 14th week (Fig. 3d).

\section{DISCUSSION}

Melatonin treatment, when administered in the German angora rabbit around the summer solstice, was efficient in suppressing the summer decrease in wool production and resulted in a considerable improvement in wool production traits. Total fleece weight as well as weight of first grade wool, quantity of wool produced per day and per $\mathrm{kg}$ of live weight and fibre length were higher in the melatonin treated group than in the controls. Due to melatonin treatment wool production increased by $14-18 \%$, and the number of hair fibres (lateral primaries and secondaries) per follicle group was found to rise by one third. Such results corroborate the hypothesis according to which the seasonal period of increased day length leads to a decrease in wool production via decreasing hair follicle activity [13]. These findings are similar to previous observations made with French angora does [1, 15] treated with melatonin in spring. The melatonin treatment administered during long days exerted an effect opposite to the length of daylight; therefore, the number of wool fibres per follicle group increased in relation to that recorded in the control group.

The MEL-treatment was effective both directly and indirectly on wool production. Having had higher the feed consumption of treated rabbits therefore their body weight increased. Heavier animals parallelly with larger body-surface can produce more fleece in accordance with other authors [7, 13]. Similar observations have been made in fur bearing animals [11, 19] and corroborate information about the role of melatonin in controlling seasonal variations in feed intake and body weight in both fur bearing animals [9] and angora rabbits [7].

With respect to the time of melatonin administration, i.e. before or after the summer solstice, no differences in total wool production were observed, but larger quantities of first grade wool were produced when melatonin was given in July. Melatonin treatment was efficient irrespective of the method of wool harvesting, but seemed to be more effective in defleeced rabbits than in shorn ones, but the defleeced rabbits have a higher hair growth rate than the shorn ones. With respect to the composition of the fleece and fibre dimensions, the method of wool harvest exerted a considerably more substantial effect on the ratio of the different fibre types and dimensions of the fibre (cross-sectional area and diameter) than melatonin treatment or sex. In defleeced rabbits a significantly higher bristle content was found than in shorn ones. In case of defleecing a better conforming to natural hair cycle is observed as after fleece removing all fibres enter in anagen phase, while by shearing fibres have different phase growth. The moulting being not in accordance with shearing, part of the bristles are falling out. This observation is important considering the processing of angora wool with regard to economic concerns, as bristly angora wool is required for the manufacte of luxury products $[10,13]$.

\section{ACKNOWLEDGEMENTS}

The authors would like to express their thanks to the staff of the Hungarian National Institute of Animal Health and Hygiene (Budapest) (Mrs. Gyuláné Stoll, Dr. Róbert Glávits and Mrs. Edit Karner) for their assistance in preparation of skin 
samples. Thanks are also due to Ms. Deborah L. Moss for her help in the translation of the text into English. The assistance of the Hungarian National Fund for Scientific Research (OTKA, project number F 017671), which supported this research work, is gratefully acknowledged, as it that of the OMFB, the Hungarian National Committee for Technical Development, and Le Ministère des Affaires Étrangères in France, for supporting scientific and technological cooperation between France and Hungary.

\section{REFERENCES}

[1] Allain D., Thébault R.G., Effects of various melatonin treatments on summer wool production in angora rabbits, in: Holdas S. (Ed.), Proceedings of the 4th World Rabbit Congress, Budapest, Hungary, Vol. 4, 1988, pp. 441-448.

[2] Allain D., Thébault R.G., A rapid method for measuring cross section characteristics of animal fibres, in: Laker J.P., Wurtmann F.J. (Eds.), European Fine Fibre Network, Occasiona Publication, Aachen, Germany, No. 4, 1995 pp. 99-110.

[3] Allain D., Thébault R.G., Rougeot J., Martinet L., Biology of fibre growth in mammals producing fine fibre and fur in relation to control by day length: relationship with other seasonal functions, European Fine Fibre Network, Occasional Publication, No. 2, 1994, pp. 23-40.

[4] Arendt J., Melatonin and the mammalian pineal gland, Chapman and Hall, London, 1995.

[5] Gebbie F.E., Forsyth I.A., Arendt J., Effects of melatonin, bromocriptine and altered light/temperature patterns on coat growth in dairy goats, European Fine Fibre Network Occasional Publication, No. 2, 1994, pp. 97-107.

[6] Hynd P.I., The nutritional biochemistry of wool and hair follicles, Anim. Sci. 70 (1999) 181-198.

[7] Lebas F., Thébault R.G., Influence of ad libitum feeding 5 weeks after plucking on wool production in angora rabbits, in: Holdas S. (Ed.), Proceedings of the 4th World Rabbit Congress, Budapest, Hungary, Vol. 3, 1988, pp. 249-253.

[8] Lincoln G.A., Photoperiod-melatonin relay in deer, Acta Vet. Hung. 46 (1998) 341-356.
[9] Martinet L., Allain D., Role of the pineal gland in the photoperiodic control of reproductive and non-reproductive functions in mink (Mustela vison), in: Photoperiodism, melatonin and the pineal, CIBA Foundation Symposium, Pittman, London, 117, 1985, pp. 170-187.

[10] Ossard H., Thébault R.G., Vrillon J.L., Allain D. Rochambeau H. de, Economic overview of the French and world markets for angora rabbit wool, European Fine Fibre Network No. 4, European workshop, Italy, 1995, pp. 35-47.

[11] Pearson A.J., Ashby M.G., Staples L.D., Effect of melatonin on body weight, appetite and seasonal fur growth in the ferret, Proc. NZ Soc. Anim. Prod. 49 (1989) 47-52.

[12] Rochambeau H. de, Genetics of the rabbit for wool and meat production (1984-1987), in: Holdas S. (Ed.), Proceedings of the 4th World Rabbit Congress, Budapest, Hungary, Vol. 2 , 1988, pp. 1-68.

[13] Rochambeau H. de, Thébault R.G. Genetics of the rabbit for wool production, CAB International 58 (1990) 1-15.

[14] Rougeot J., Thébault R.G., Variations saisonnières de la composition et de la structure du pelage, exemple du lapin angora, Ann. Zootech. 32 (1983) 287-314.

[15] Rougeot J., Thébault R.G., Allain D., Suppression de la chute estivale de la production du poil chez la lapine angora par la pose d'implants de melatonine, Ann. Zootech. 35 (1986) 363-372.

[16] SAS, Version 6.09, SAS INST. INC. Cary, NC, USA, 1993

[17] Schlolaut W., Angora rabbit housing and management, J. Appl. Rabbit Res. 10 (1987) 164-169.

[18] Thébault R.G., Vrillon J.L., Seasonal effects on angora rabbit production, European Fine Fibre Network, Occasional Publication, No. 2, 1994, pp. 51-61.

[19] Valtonen M., Jalkanen L., Blomstedt L., Possible use of melatonin in fur animal production, Proceeding of the 3rd International Symposium of Fur Animal Science, Leipzig, Germany, 1990, $8 \mathrm{p}$.

[20] Visilog, User and programmer guide (version 3.6), Noesys, Domaine technologique de Saclay, Orsay Cedex, France, 1988. 